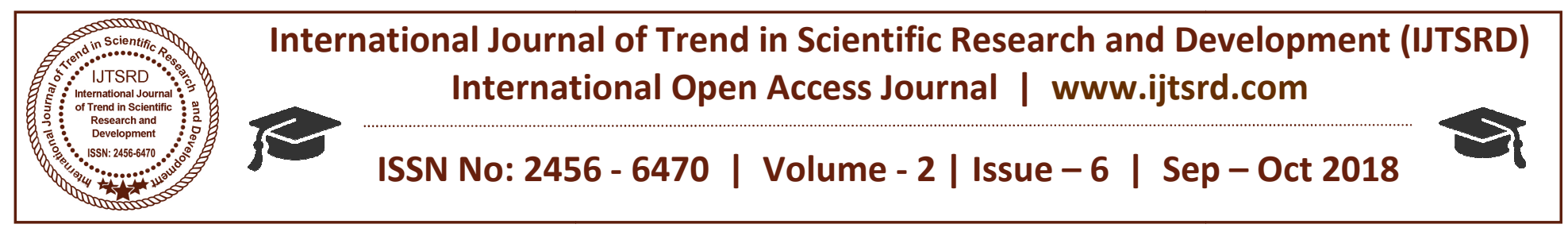

\title{
Use of Industrial Waste in Road Embankment
}

\author{
Bothsa Kumari ${ }^{1}$, Ch. Damodhar Naidu ${ }^{2}$, Pinninti Dileep Kumar ${ }^{3}$ \\ ${ }^{1,3}$ Student, ${ }^{2}$ Assistant Professor \\ ${ }^{1,2}$ Gokul Group of Institutions, Bobbili, Andhra Pradesh, ${ }^{3}$ Andhra University, Visakhapatnam, Andhra Pradesh
}

\section{ABSTRACT}

The scarcity of soil which suits for construction activities by fulfilling geotechnical characteristics is forcing the pavement engineers to look for alternative materials for construction activity. On the other hand due to the rapid industrialization there is sharp increase in the number of crushing units, steel producing factories in so many states and the country as well. The crusher dust and Blast furnace slag obtained from these industries are collected and tested for various geotechnical characterizations. The suitability of partial or full replacement is checked by conducting CBR tests on various mix portions. In the present investigation, crushed stone tas coarse aggregate mixed with Crusher Dust, Blast Furnace Slag and Sand as fine aggregate and tested for compaction (OMC and MDD) and strength (CBR) characteristics to suit as base course material along with their relative performance. It is also studied partial replacement of Crusher Dust, Sand by Slag particles $(50 \%)$ with respect to their gradation mixes. From all the studies it is identified that average gradation obtained higher VBR values than lower and upper gradation for all types of fine aggregates due to their dense or compactness by possessing effective well graded conditions. Lower gradations obtained CBR values nearing to their average gradation which are higher than upper gradation mixes. The same trends are also observed in case of 50\% replacement. Hence replacement of natural soil like gravel, sand by crusher dust and slag particles with their maximum utilization such as partial or full replacement with crushed stone particles attaining CBR values greater than $80 \%$ can be used in road construction as basecourse material.

Keyword: Crushed Stone Dust, Sand, Blast Furnace Slag, Crushed dust

\section{INTRODUCTION}

Civil Engineering structures require bulk quantities of natural soils to suit as construction and foundation material and to meet certain specifications such as stones, sands, gravel soils etc. Some materials are durable and some of them have been continuously deforming when contacted with water. These result in development of failures with respect to loss of strength and finally subjected to abnormal settlements which threat the life of the structure as a whole.

Now-a-days industrial wastes like Crusher Dust, Pond ash, Slag, etc. have been gaining their prominence to be used as civil engineering material as an individual or mixed with natural soils or stones or admixture to suit as construction materials. Several thinkers have been in the field of research on the utilization in various parts of civil engineering. Geotechnical engineering is a promising area for the utilization in the areas of road construction material and other geotechnical material.

A number of researchers have made their contributions for the utilization of above said materials in various geotechnical applications. Soosan et.al (2000, 2001) identified that crusher dust exhibited high shear strength and beneficial for its use as geotechnical material. Sridhar an A et.al (2005, 2006) reported that high CBR and shearing resistance values can enhance their potential use as sub-base material in flexible pavements and also as an embankment material. Praveen Kumar et.al (2006) conducted CBR tests on stone dust as a sub-base material. Wood et.al (1993) identified that the physical properties, chemical composition and mineralogy of quarry dust varies with aggregate type and source. Collins R.J et.al (1994) studied quarry dust in highway constructions. 


\section{MATERIALS AND PROPERTIES Material Used:}

The materials used in this investigation are:

$>$ Crusher dust

$>$ Sand

$>$ Blast Furnace Slag

$>$ Crushed Stone

\subsubsection{Crusher Dust:}

Crusher dust is a common by-product of mining and quarrying. Crusher dust (CD) was obtained from local stone crushing plants near Visakhapatnam, Andhra Pradesh. Rather than being discarded as a waste material however, recycled crusher dust has many practical applications around the home and in construction. Using crusher dust in lieu of other materials can have resounding environmental and economical benefits. With fine particles like soft sand, crusher dust can be used as a cost-effective filling and packing material around water tanks; blended with natural sands to improve concrete shrinkage and water demand; and as a material to back-fill trenches with. It can also be used as a concrete aggregate used to create distinctive textures and as a substitute for concrete when creating pathways and driveways. The production costs of crusher dust are relatively low compared to other building materials. Crusher dusts use less water than other alternatives and have excellent load bearing capabilities and durability. Crusher dust is fire and heat resistant; non-plastic; and alkaline when exposed to moisture, making it an ideal material to use in construction.

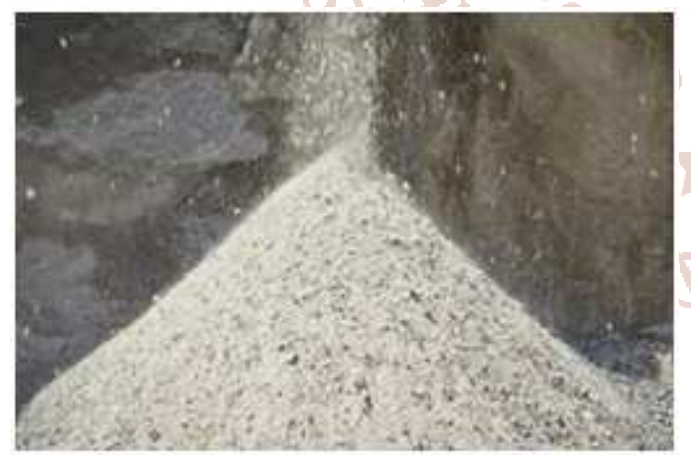

Figure3.1 Crusher Dust

\subsubsection{Sand:}

Sand was collected from river Nagavali, Srikakulam, Andhra Pradesh, India. Sand is a naturally occurring granular material composed of finely divided rock and mineral particles. It is defined by size, being finer than gravel and coarser than silt. Sand can also refer to a textural class of soil or soil type; i.e. a soil containing more than $85 \%$ sand-sized particles by mass.

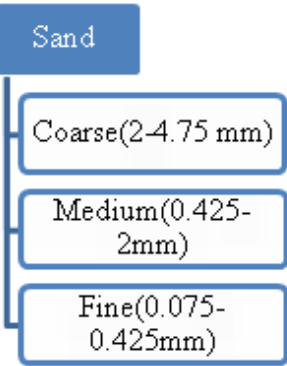

\subsubsection{Blast Furnace Slag:}

Blast furnace route of Iron making will probably remain the major process for pig-iron production, to be finally converted to steel, despite the speedy deflection of coking coal reserves in India and elsewhere in the world. It is thus important to understand and study the factors responsible for influencing the smoothness of operation, coke consumption, and quality of hot metal produced and over all, the associated green-house problem. Blast furnace slag is a nonmetallic coproduct produced in the process. It consists primarily of silicates, aluminosilicates, and calcium-alumina-silicates. The molten slag, which absorbs much of the sulfur from the charge, comprises about 20 percent by mass of iron production. Figure presents a general schematic, which depicts the blast furnace feedstocks and the production of blast furnace coproducts (iron and slag). Different forms of slag product are produced depending on the method used to cool the molten slag. These products include air-cooled blast furnace slag (ACBFS), expanded or foamed slag, pelletized slag, and granulated blast furnace slag.

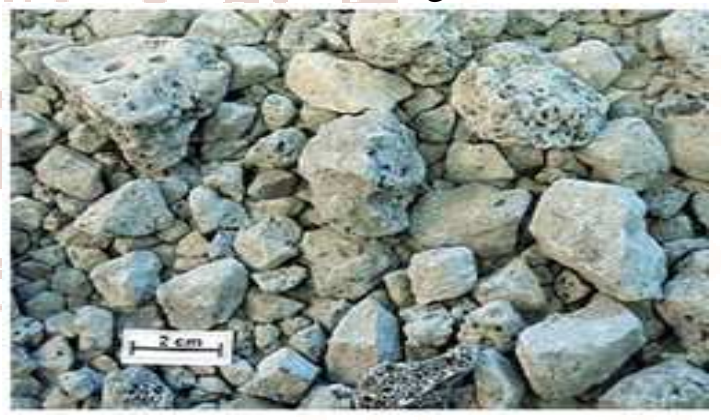

Figure3.2 Blast Furnace Slag

\subsubsection{Properties of Soil:}

The following tests were conducted on the soil. The index and engineering properties of soil were determined.

1. Grain size analysis confirming (IS: 2720-part 4, 1985)

2. Consistency limits or Atterberg's Limits using Uppals method confirming (IS: 2720-part 5, 1985)

3. Compaction test confirming (IS: 2720- Part 8: 1983) 
4. California bearing ratio test confirming (IS: 2720Part 16: 1987)

\subsubsection{CONSISTENCY LIMITS (IS: 2720- PART 5, 1985)}

\section{Liquid Limit}

The liquid limit test was conduted as per I.S:2720 (part - v)-1970. The test is conducted on soil after passing 425 micron I.S. Sieve using casagrande apparatus.

\section{Plastic Limit}

The plastic limit test was coducted as per I.S:2720 (part - v)-1970.

\section{EXPERIMENTAL METHODOLOGY}

The soil sub-grade is a layer of natural soil prepared to receive the layers of pavement materials placed over it. The loads on the pavement are ultimately received by the soil sub-grade for dispersion to the earth mass. It is essential that at no time, the soil subgrade is overstressed. It means that the pressure transmitted on the top of the sub-grade is within the allowable limit, not to cause excessive stress condition or to deform the same beyond the elastic limit. Therefore it is desirable that at least top $50 \mathrm{~cm}$ layer of the sub-grade soil is well compacted under controlled conditions of optimum moisture content and maximum dry density. It is necessary to evaluate the strength properties of the soil sub-grade. This helps the designer to adopt the suitable values of the strength parameter for design purposes and in case this supporting layer does not come up to the expectations, the same is treated or stabilized to suit the requirements. Many tests are known for measuring the strength properties of the sub grades. Mostly the test is empirical and is useful for their correlation in the design. The common strength tests for the evaluation of soil sub-grade are:

$>$ California bearing ratio test.

$>$ California resistance value test.

$>$ Triaxial compression test.

$>$ Plate bearing test.

These tests have been explained in detail in Chapter 6 and in the book Highway Materials Testing by the authors. California Bearing Ratio (CBR) test is a penetration test, evolved for the empirical method of flexible pavement design. The CBR test is carried out either in the laboratory on prepared specimens or in the field by taking in-situ measurements. This test is also carried out to evaluate the strength of other flexible pavement component materials. California resistance value is found by using Hveemstabilo meter. This test is used in an empirical method of flexible pavement design based on soil strength.

Though tri-axial test is considered as the most important soil strength test, still the test is not very commonly used in structural design of pavements. This is because only a few theoretical methods make use of this tri-axial test results.

The plate bearing test is carried out using a relatively large diameter plate to evaluate the load supporting capacity of supporting power of the pavement layers. The plate bearing test is used for determining the elastic modulus of sub-grade and other pavement layers. The results of the plate bearing tests are used in flexible pavement design method like McLeod method and the method based on layer system analysis by Bur mister. Also the test is used for the determination of modulus of sub-grade reaction in rigid pavement analysis by Westergaard's approach.

\section{RESULTS AND DISCUSSION CRUSHER DUST:}

Crusher dust was obtained from local stone crushing plants near Visakhapatnam, Andhra Pradesh, India and subjected to various geotechnical characterizations as per IS2720. The results are shown in table 4.1.

Table4.1Geo Technical Properties of Crusher Dust

\begin{tabular}{|c|c|}
\hline Property & Value \\
\hline \multicolumn{2}{|c|}{ Particle size (mm) } \\
\hline Gravel Size \% & 08 \\
\hline Sand Size \% & 86 \\
\hline Fines $\%$ & 06 \\
\hline Silt Size \% & 06 \\
\hline Clay Size \% & 0 \\
\hline \multicolumn{2}{|l|}{ Consistency } \\
\hline Liquid limit (\%) & NP \\
\hline Plastic limit (\%) & NP \\
\hline Plasticity index & NP \\
\hline $\mathrm{C}_{\mathrm{u}}$ & 21.0 \\
\hline $\mathrm{C}_{\mathrm{c}}$ & 1.15 \\
\hline IS classification & SW \\
\hline \multicolumn{2}{|c|}{ Compaction Characteristics } \\
\hline OMC $(\%)$ & 10 \\
\hline $\operatorname{MDD}(\mathrm{g} / \mathrm{cc})$ & 2.1 \\
\hline \multicolumn{2}{|c|}{ Strength Characteristics } \\
\hline CBR \% & 14 \\
\hline Angle of shearing resistance (ஜ́) & 40 \\
\hline
\end{tabular}


4.2 Grain Size Distribution Characteristics:

To know the different sizes of particles and their percentages in the Crusher Dust a sample, dry analysis (sieve analysis) was conducted as per IS2720 part 4 and the results are shown in the table 4.2 and figure 4.1 .

Table4.2Gradation test data for Crusher dust

\begin{tabular}{|c|c|c|}
\hline S. No. & Sieve Size $(\mathbf{m m})$ & \% Finer \\
\hline 1 & 10 & 100 \\
\hline 2 & 4.75 & 92 \\
\hline 3 & 2.36 & 62 \\
\hline 4 & 1.18 & 46 \\
\hline 5 & 0.6 & 34 \\
\hline 6 & 0.3 & 24 \\
\hline 7 & 0.15 & 15 \\
\hline 8 & 0.075 & 6 \\
\hline 9 & 0.06 & 3 \\
\hline 10 & 0.05 & 0 \\
\hline
\end{tabular}

\subsubsection{Compaction Characteristics:}

To know the compaction characteristics Crusher dust was subjected for Modified Proctror's test as per IS2720 part 8 and the results are as shown in the table 4.3 and figure 4.2.

Table4.3Compaction curve of crusher dust

\begin{tabular}{|c|c|c|}
\hline $\begin{array}{c}\text { S. } \\
\text { No. }\end{array}$ & Moisture Content \% & $\begin{array}{c}\text { Dry Density } \\
(\mathrm{G} / \mathrm{Cc})\end{array}$ \\
\hline 1 & 2 & 1.70 \\
\hline 2 & 4 & 1.55 \\
\hline 3 & 6 & 1.60 \\
\hline 4 & 8 & 1.80 \\
\hline 5 & 10 & 2.10 \\
\hline 6 & 12 & 2.00 \\
\hline 7 & 14 & 1.90 \\
\hline 8 & 16 & 1.82 \\
\hline 9 & 18 & 1.70 \\
\hline 10 & 20 & 1.60 \\
\hline
\end{tabular}

From the test results of crusher dust, the following identifications are made. The grain size distribution of crusher dust shows that it consists of $86 \%$ of sand size and $6 \%$ of silt size particles. Majority of crusher particles are coarse to medium sand ranges with rough surface texture. Its consistency shows non-plastic and incompressible. Based on BIS, it is classified as well graded particles with non-plastic fines (SWN) with $\mathrm{C}_{\mathrm{u}}$ as 21 and $\mathrm{C}_{\mathrm{c}}$ as 1.15 . Compaction characteristics of crusher dust under modified proctor compaction test have an Optimum Moisture Content of $10.0 \%$ and Maximum Dry Density of $2.1 \mathrm{~g} / \mathrm{cc}$. From the compaction curve it can also be seen that crusher dust attains high densities with wide variation of moisture contents and increases the workability at high moisture contents. It also exhibited high shear strength values such as angle of shearing resistance ( $\varphi$ ) of $40^{\circ}$ under undrained condition and CBR of $14.0 \%$. It has good drainage characteristics with coefficient of permeability as $3.4 \times 10^{-3} \mathrm{~cm} / \mathrm{sec}$.

\section{BLAST FURNACE SLAG:}

Blast Furnace Slag (BFS) was collected from Vizag Steel Plant, Visakhapatnam, Andhra Pradesh, India. The collected slag was dried and subjected for various geotechnical characterizations such as gradation, compaction characterisation, strength, permeability etc., as per IS 2720 and the test results are shown in Table 4.4.

\section{CONCLUSIONS}

\section{Summary and Conclusions}

Crusher dust is a residue obtained from stone crushing plants after making required sizes for various civil engineering projects. From test results it is identified that crusher dust is a coarse grained dominated by coarse to medium sand particles which are incompressible and non-plastic material. Its characteristics are similar to sand. It attained high strength values in terms of angle of shearing resistance as $40^{\circ}$ and CBR as 14 . It also attained high dry densities with wider variation of moisture contents and exhibited MDD as $2.1 \mathrm{~g} / \mathrm{cc}$ and OMC as $10 \%$. Considering the above compaction and strength characterisation crusher dust can be used as filling material in embankments, low lying areas, foundation material, earth retaining material and sub-grade material.

Blast furnace slag is a residue obtained from melting of steel from blast furnace slag dominated by fine sand size particles which are non-plastic and incompressible. Its characteristics are also similar to sand. It also attained high strength values in terms of ' $\varphi$ ' as $43^{\circ}$ and CBR as 12. It also attained good maximum dry density value by maintaining high water content. From these characteristics blast furnace slag can be effectively used in embankments, filling areas, foundations and also in roads as sub-grade material. 
International Journal of Trend in Scientific Research and Development (IJTSRD) ISSN: 2456-6470

Usually natural soils have lot of importance in their uses as geotechnical constructions.

1. Individually Crusher Dust and Blast Furnace Slag are coarse grained materials which attained high CBR values i.e., $14 \%$ and $12 \%$ (> 10\%).

2. Crusher Dust, Crusher Stone and Blast Furnace Slag have attained high Maximum Dry Densities as $2.1,1.85$ and $1.58 \mathrm{~g} / \mathrm{cc}$ respectively and can be used as sub base and base course materials

3. Crushed Stone is replaced by Blast Furnace Slag and Crusher Dust by $50 \%$ to attain high CBR value i.e., $116 \%, 106 \%$ and $96 \%$. Respectively greater than $80 \%$ can be used as base course material.

4. Crushed dust can be used as alternative to sand in geotechnical aspects for partial and full replacements.

\subsection{SCOPE FOR FURTHER STUDY}

In this study we have used crushed stone aggregate with crushed dust, sand and slag as a mixture and studied its mechanical and strength characterisations.

Further studies can be carried out by replacing Crushed Stone aggregate with slag materials like steel slag, zinc slag etc. and crusher dust can be replaced by other industrial wastes like pond ash, fly ash, GGBS etc. to obtain better results. These aforesaid materials can be used in flexible pavements like sub base, base and wet mix macadam.

\section{REFERENCES}

1. Akshay Kumar Sabat, "A Study on Some Geotechnical Properties of Lime Stabilized Expansive Soil - Quarry Dust CBR value of Mixes ," International Journal of Emerging trends in Engineering and Development, Issue 2, Vol.1 January-2012.

2. Ahmed and Lovell (1993) - "Rubber soils as Light weight Geo materials", Transportation Research Record, 1422, TRB, National Research Council, Washington DC, PP 61-70.

3. Ahmed E. Ahmed and Korud A. E., 1989, "Properties of concrete incorporating natural and crushed sand and very fine sand" American
Society for Civil engineers, (ASCE) Material Journal, Vol. 86(4), pp 417424.

4. Bindhu Lal, MD Shafique Alam and Sushama Kiran (2014) " Use Of Stone Dust From Construction Site As A Stabilizing Agent In Flexible Pavement Construction: A Case Study" International Journal of Structural and Civil Engineering Research ISSN 2319 - 6009 www.ijscer.com Vol. 3, No. 4

5. Baleshwar Singh and Valliapan Vinot (2011) "Influence of Waste Tire Chips on Strength Characteristics of Soils" Journal of Civil Engineering and Architecture, USA,ISSN 19347359, Volume 5, No. 9

6. Bernal, A., Salgado, R. and Lovell, C.W., (1997), "Tire Shreds and Rubber-sand as Lightweight Backfill Material", accepted for publication as a technical paper in the Journal of Geotechnical and Geo-environmental Engineering.

7. Ghatge Sandeep Hambirao, Dr. P. G. Rakaraddi (2014) "Soil Stabilization Using Waste Shredded Rubber Tyre Chips" IOSR Journal of Mechanical and Civil Engineering (IOSR-JMCE) e-ISSN: 2278-1684, p-ISSN: 2320-334X, Volume11, Issue 1 Ver. V, PP 20-27.

8. Hameed M S and A. S. S. Sekhar (2009), "Properties of green concrete containing quarry rock dust and marble sludge powder as fine aggregate", ARPN. Journal of Engineering and Applied Sciences; vol.4(4); pp. 83-89.

9. Ilangovana, R. Mahendrana, N. and Nagamani, K., (2008), "Strength and Durability Properties of Concrete containing Quarry Rock Dust as Fine Aggregates", ARPN Journal of Engineering and Applied Science, Vol3 (5), pp 20ᄀ26.

10. Illangovan R. and Nagamani K. 2006. Studies on Strength and Behavior of Concrete by using Crusher Dust as Fine Aggregate. CE and CR journal, New Delhi. October. Pp. 40-42.

11. IS 2720-4: Methods of test for soils, Part 4: Grain size analysis. 